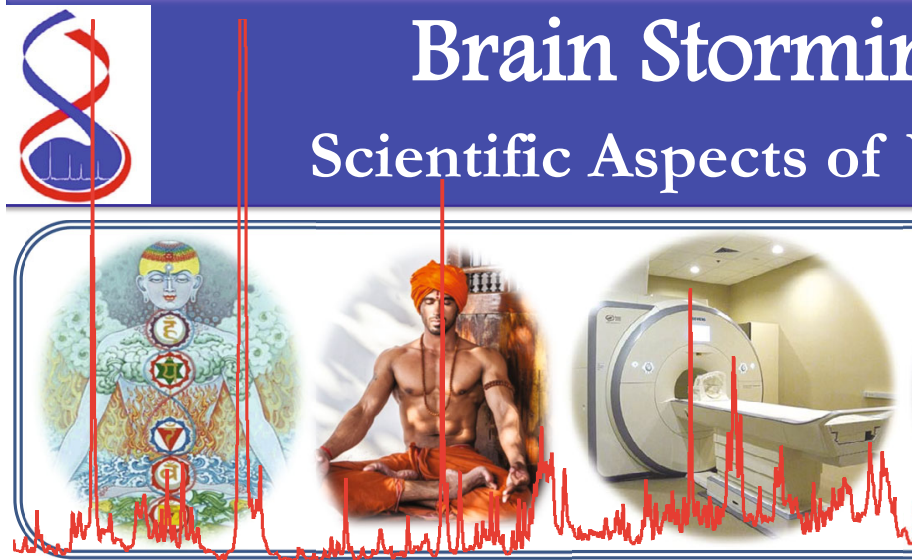

Date (Time): March 04, 2015 (10:30 to 16:30 Hrs)

Venue: Centre of Biomedical Research, SGPGIMS Campus, Raibareli Road, Lucknow

Message from the Convener (Prof. C L Khetrapal): The memorable suggestion of the honourable Prime Minister, India in the UN about the International YOGA DAY and accepted by 177 countries worldwide prompted me to draw the kind attention of Indian scientific community towards scientific evidence of the positive effects of YOGA and MEDITATION on human health based on the research being carried out in India and abroad. In my opinion such type of work if pursued with full force, can bring India on the front line for giving a scientific pictorial method for improving human health and behaviour and achieving world peace and happiness.

The functional MRI results from our Centre show that the OM sound influences the attention process, motor coordination, and auditory perception. The SOHAM meditation regulates the attention, cognitive aspects of emotional processing and the spatially guided behaviours. The negative thoughts excite the same area of the brain as the one in mentally depressed persons.. Similarly some of the Yoga exercises are found to increase the GABA concentration in humans to the extent of $27 \%$ (a study reported by Boston School of Medicine).

To evolve a national level strategy to pursue such activities in the country, we decided to organize a national level brain storming session on March 04, 2015 at the Centre of Biomedical Research, Sanjay Gandhi Post Graduate Research Institute of Medical Sciences Campus, Raebareli Road, Lucknow. There will be talks and discussions on the topic by the internationally reputed scientists from premier institutions involved in research and education and exhibiting vast experience in the field, in the overall societal interest. Their recommendations to pursue such activities, especially, in biomedical and clinical context may then be forwarded to appropriate authorities to launch such a programme on June 21, 2015, the International Yoga day.

\section{Contact for any query: Prof. Saumen Hajra}

(Email: saumen.hajra@cbmr.res.in; Mobile: +91-9434706117)

\title{
Session on
}

\section{and Meditation}

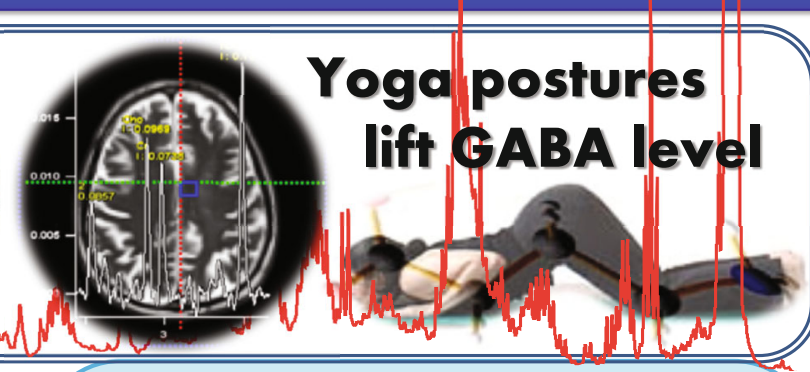

Session Speakers

Prof. C L Khetrapal, CBMR, Lucknow (Convener) Prof. Goverdhan Mehta, University of Hydrabad

Prof. Ganesh Pandey, CBMR, Lucknow

$\circ$ Prof. R. C. Tripathi, CBCS, Allahabad University

Prof. N.R. Jagannathan, AIIMS, New Delhi

- Prof. Narayan Srinivasan, CBCS, Allahabad University

Prof. P. N Tandon, NBRC, Manesar, Gurgaon

Prof. Seyed Hasnain, IIT Delhi

- Prof. Girish Tripathi, BHU, Varanasi

Prof. R K Naidu, Psychology Department, Allahabad University

Dr. Ashish Arora, CDRI, Lucknow

Ms. Radha Behen BrahmaKumari Ashram, Lucknow

Shri Rakesh Mittal (IAS), Kabir Shanti Mission, Lucknow

Shri Anant Shri, Anant Path, Lucknow

\begin{tabular}{|c|c|c|}
\hline \multicolumn{3}{|c|}{ Progremme } \\
\hline Welcome & $10: 30$ & Prof. Ganesh Pandey \\
\hline Background & $10: 35$ & Prof. C.L. Khetrapal \\
\hline \multicolumn{3}{|c|}{$\begin{array}{l}\text { Session-I }(10: 45 \text { to } 13: 30] \\
\text { Chairman: Prof. P. N Tandon }\end{array}$} \\
\hline \multicolumn{3}{|c|}{ Views from the Experts } \\
\hline $10: 45$ & & Prof. Goverdhan Mehta \\
\hline $10: 55$ & & Prof. R. C. Tripathi \\
\hline 11:05 & & Prof. Girish Tripathi \\
\hline $11: 15$ & & Prof. Narayan Srinivasan \\
\hline $11: 25$ & & Prof. N.R. Jagannathan \\
\hline $11: 35$ & & Shri Rakesh Mittal \\
\hline $11: 45$ & & Shri Anant Shri \\
\hline 11:55 & & Ms. Radha Behen \\
\hline $12: 05$ & & Prof. Seyed Hasnain \\
\hline $12: 55$ & & Prof. R K Naidu \\
\hline 13:05 & & Dr. Ashish Arora \\
\hline 13:15-13:30 & & Session Chairman's Remarks and Views \\
\hline $13: 30-14: 30$ & & Lunch \\
\hline \multicolumn{3}{|c|}{$\begin{array}{c}\text { Session-II }[14: 30 \text { to } 15: 00] \\
\text { Chairman: Prof. Governdhan Mehta }\end{array}$} \\
\hline \multicolumn{3}{|r|}{ Discussion } \\
\hline \multicolumn{3}{|c|}{$\begin{array}{l}\text { Session -III }(15: 00 \text { to } 16: 00] \\
\text { Chairmen: Prof. R. C. Tripathi and Prof. Saumen Hajra }\end{array}$} \\
\hline \multicolumn{3}{|c|}{ Recommendations } \\
\hline 16:00-16:30 & & Tea \\
\hline
\end{tabular}

\section{CENTRE OF BIOMEDICAL RESEARCH (CBMR)}

(Formerly Centre of Biomedical Magnetic Resonance)

Sanjay Gandhi Postgraduate Institute of Medical Sciences Campus, Raebareli Road, Lucknow - 226014, U.P. (INDIA) 